\title{
The Effect on the Performance of Cement Grinding Aid Components
}

\author{
GUO Yan-mei ${ }^{1, a}$, SUN Shao-fei, ${ }^{2, b, *}$ \\ ${ }^{1 .}$ Hohhot Construction Engineering Quality Supervision Station ,Hohhot 010000 ,China \\ 2. Inner Mongolia University of Science \&Technology ,Baotou 014010, China \\ ${ }^{\mathrm{a}}$ Tel.13314719522, ${ }^{\mathrm{b}}$ email:1197168195@qq.com \\ *SUN shao-fei , Master Dergree Candidate, Mainly engaged in the research of high performance \\ concrete.Tel:15049209157
}

Keywords: Cement grinding aid, Fineness, Compressive strength, Size distribution.

\begin{abstract}
In this paper, By choosing four kinds of grinding aids better one-component, The grinding aid of cement grinding aids is determined by orthogonal optimization. By adding different inorganic reinforcing components, Developed a cement grinding aids. The result turns out, compared with blank sample, the adulteration of grinding aid leads compression strength of $3 \mathrm{~d}, 7 \mathrm{~d}$ and $28 \mathrm{~d}$ respectively are improved $17.9 \%, 17.8 \%$ and $16.8 \%$, cement fineness to reduce by $63.1 \%$ and specific surface area to increase about $10.6 \%$. Meanwhile, cement particles ranging 3-32 $\mu \mathrm{m}$ is improved $11.3 \%$, which optimizes the grain composition of cement and increases strength of cement. The experimental research to provide technical support for the future development of cement technology.
\end{abstract}

\section{Introduction}

With the rapid development of construction industry, people pay much more attention to the quality of cement. As we all know that, the production process of cement can be broadly divided into "two grindings and burn", which means raw meal preparation, clinker calcining and cement grinding, and cement grinding is the most important process in the whole cement production. However the fineness of cement grinding to a certain degree, there will be "reunion" phenomenon". this is because the cement produce electric charge in the process of grinding, the positive and negative charges on cement particle's surface attract each other, and cement grinding aid is a good way to avoid the occurrence of this phenomenon. Because of its lower cement fineness, increasing specific surface area, optimizing the grain size distribution of cement particles, reduce grinding energy, and increasing production, Cement grinding aid is widely used in cement industry ${ }^{[1-4]}$. 
Below chemical regent are normally used as cement grinding aid: three isopropanolamine, ethylene glycol, triethanolamine, sorbitol, diethylene glycol, glycerin, etc. Because of the bad adaptability, stability and imperfect function, single-component cement grinding aid is difficult to meet the requirements of grinding aid; Also the macromolecular synthetic grinding agent technology is still not perfect, cannot be applied to the actual production ${ }^{[5-6]}$, So the composite cement grinding aid has become one of the mainstream of the cement industry. Composite cement grinding aid is by a variety of single component and grinding aid distribution, and the interaction of different monomer component, to make composite grinding agent has good grinding effect, good stability, wide adaptability of multiple effect.

\section{Experiment}

\subsection{Experiment Material}

\subsubsection{Binding Material}

In this test, we use clinker from Wuhai in Inner Mongolia, natural gypsum. The chemical composition of clinker and gypsum are shown in table 1, the cement clinker without grinding aids' physical properties such as table 2 .

Tab.1 Chemical composition of raw materials

$/ \%$

\begin{tabular}{ccccccccc}
\hline $\begin{array}{c}\text { Raw } \\
\text { material }\end{array}$ & $\mathrm{SiO}_{2}$ & $\mathrm{Al}_{2} \mathbf{O}_{3}$ & $\mathrm{Fe}_{2} \mathbf{O}_{3}$ & $\mathbf{C a O}$ & $\mathrm{MgO}$ & $\mathrm{Loss}$ & $\mathbf{S O}_{3}$ & $\sum$ \\
\hline Clinker & 24.98 & 6.42 & 3.56 & 60.90 & 2.42 & 0.86 & 0.56 & 99.7 \\
Gypsum & 16.16 & 2.46 & 0.82 & 25.18 & 2.24 & 17.75 & 29.73 & 94.34 \\
\hline
\end{tabular}

Tab.2 Cement clinker physical properties

\begin{tabular}{|c|c|c|c|c|c|c|c|c|c|}
\hline & \multirow{2}{*}{$\begin{array}{c}\text { fineness } \\
(45 \mu \mathrm{m}, \%)\end{array}$} & \multirow{2}{*}{$\begin{array}{l}\text { specific } \\
\text { surface } \\
\text { area } \\
\left(\mathrm{m}^{2} / \mathrm{kg}\right)\end{array}$} & \multirow{2}{*}{$\begin{array}{c}\text { water } \\
\text { requirement } \\
\text { of normal } \\
\text { consistency } \\
(\%)\end{array}$} & \multicolumn{2}{|c|}{$\begin{array}{l}\text { setting time } \\
\quad(\min )\end{array}$} & \multicolumn{2}{|c|}{$\begin{array}{l}\text { rupture } \\
\text { strength } \\
(\mathrm{MPa})\end{array}$} & \multicolumn{2}{|c|}{$\begin{array}{c}\text { compressive } \\
\text { strength } \\
(\mathrm{MPa})\end{array}$} \\
\hline & & & & $\begin{array}{l}\text { initial } \\
\text { setting } \\
\text { time }\end{array}$ & $\begin{array}{l}\text { final } \\
\text { setting } \\
\text { time }\end{array}$ & $3 d$ & $28 \mathrm{~d}$ & $3 d$ & $28 \mathrm{~d}$ \\
\hline Cement & 10.3 & 450 & 24.6 & 128 & 162 & 5.4 & 7.9 & 24.7 & 50.0 \\
\hline
\end{tabular}

\subsubsection{Grindling Aid}

Selection of grinding agent component and its molecular structure as shown in table 3. 
Tab.3 Name abbreviation and structural formula of grinding aids components

\begin{tabular}{|c|c|c|}
\hline Component name of grinding aids & Abbreviation in this paper & Structural formula \\
\hline Triethanolamine & TEA & $\mathrm{N}\left(\mathrm{CH}_{2} \mathrm{CH}_{2} \mathrm{OH}\right)_{3}$ \\
\hline Triisopropanolamine & TIPA & $\mathrm{C}_{9} \mathrm{H}_{22} \mathrm{NO}_{3}$ \\
\hline Glycerin & GLY & $\mathrm{HOCH}_{2} \mathrm{CHOHCH}_{2} \mathrm{OH}$ \\
\hline Sorbitol & MDBS & $\mathrm{C}_{6} \mathrm{H}_{14} \mathrm{O}_{6}$ \\
\hline Ethylene glycol & EG & $\mathrm{HOCH}_{2} \mathrm{CH}_{2} \mathrm{OH}$ \\
\hline Sodium sulfate & $\mathrm{Na}_{2} \mathrm{SO}_{4}$ & $\mathrm{Na}_{2} \mathrm{SO}_{4}$ \\
\hline Sodium thiosulfate & $\mathrm{Na}_{2} \mathrm{~S}_{2} \mathrm{O}_{3}$ & $\mathrm{Na}_{2} \mathrm{~S}_{2} \mathrm{O}_{3}$ \\
\hline Sodium chloride & $\mathrm{NaCl}$ & $\mathrm{NaCl}$ \\
\hline Sodium carbonate & $\mathrm{Na}_{2} \mathrm{CO}_{3}$ & $\mathrm{Na}_{2} \mathrm{CO}_{3}$ \\
\hline Sodium hydroxide & $\mathrm{NaOH}$ & $\mathrm{NaOH}$ \\
\hline
\end{tabular}

\subsection{Experimental Method}

\subsubsection{Grinding Method}

According to the $95 \%$ clinker $+5 \%$ gypsum cement mixing ratio, when the grinding clinker (1-7 mm), gypsum and grinding agent to join together $\Phi 500 \times 500$ national cement plant in the unified test standard laboratory mill grinding together, each time grinding $5 \mathrm{~kg}$, grinding time for $40 \mathrm{~min}$, the release time for $5 \mathrm{~min}$.

\subsubsection{Performance Test}

(1) The cement fineness determination basis of (GB/T1345-2005) 《Cement fineness testing method Sieve analysis method》;Specific surface area measurement basis of (GB/T8074-2008) 《Cement specific surface area measurement method (Bertrand method)》;Cement strength measurement basis of (GB/T17671-1999) 《Cement mortar strength testing method (ISO method) 》。

(2) Cement particle size distribution with BT - 2001 laser particle size analyzer (dry).

\subsubsection{Cement Grinding Aid Compound Process}

Choose 5 kinds of single-component grinding agent which are commonly used in market for experiment, determine the scope of the content; Choose single-component grinding agent with good effect for orthogonal optimization, determine the best mix proportion and amount. In the composite grinding aid system, keep the same of grinding components, redistribute the grinding components with different kinds of inorganic enhancement composition, Study the influence that different inorganic components affect of cement performance, To determine the proportion of cement grinding aid.

\section{Results and Discussion}

\subsection{Effect of monocomponent grinding aid on cement performance}

All information show that, Organic alcohol amine especially triethanolamine and three 
isopropanolamine, they have significant effect on cement grinding and enhancement; Polyol molecules has good grinding effect, but slightly of enhance effect; Inorganic salt is helpless for grinding function, strengthen effect is good ${ }^{[4]}{ }^{[7]}$. Therefore, select of triethanolamine, three isopropanolamine, ethylene glycol, glycerol and sorbitol as grinding components, Study of 5 kinds of grinding components, Grinding dosage control components from $0.01 \%$ to $0.04 \%$ ( according to the quality of cement, similarly here in after), The result is shown below.

\subsubsection{Effect of monocomponent grinding aid on cement fineness and specific area}

Effect of monocomponent grinding aid on cement fineness and specific area, As shown in figure 1:
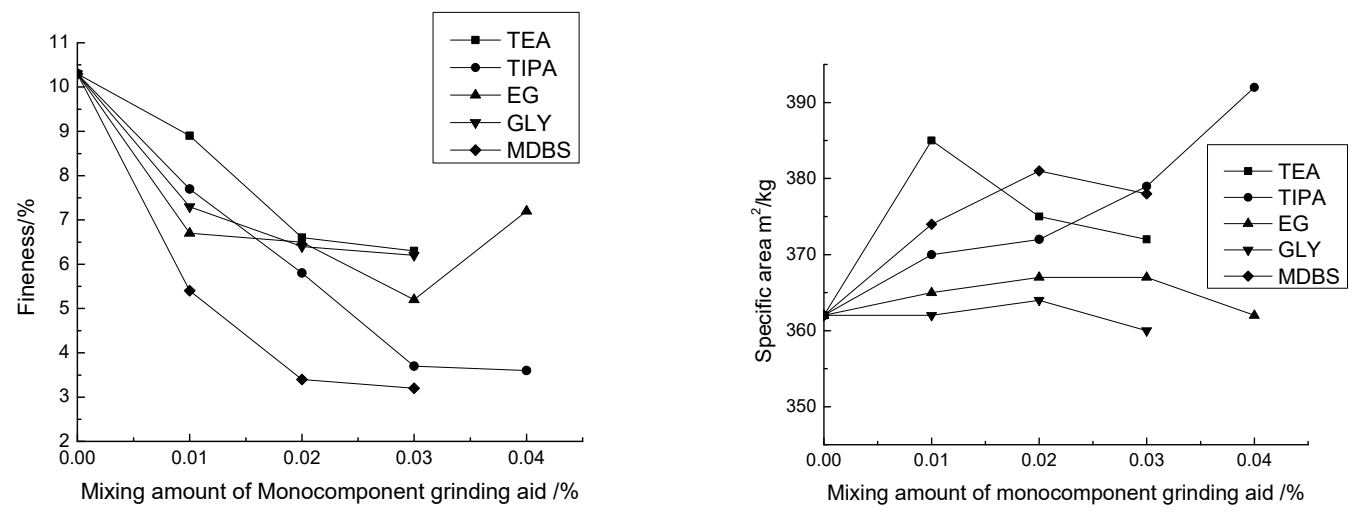

Fig.1 Effect of monocomponent grinding aid on cement fineness and specific area

As shown in figure 1, the one-component grinding agent of cement fineness and specific surface area has a certain effect. Compared with the blank group, dosage of triethanolamine was $0.02 \%$, cement fineness is $38.4 \%$ lower, specific surface area increased by $3.9 \%$; Three isopropyl alcohol amine content was $0.04 \%, 65.0 \%$ lower cement fineness, specific surface area increased by $8.9 \%$; Ethylene glycol content was $0.03 \%, 50.0 \%$ lower cement fineness, specific surface area increased by $1.3 \%$; Glycerin content was $0.02 \%, 38.2 \%$ lower cement fineness, specific surface area increased by $1.9 \%$; Sorbitol content was $0.02 \%, 66.6 \%$ lower cement fineness, specific surface area increased by $5.1 \%$. Test data shows that above one-component grinding agents have certain effect of improving cement fineness and specific surface area, has a positive effect for the preparation of the composite cement grinding aid.

\subsubsection{Effect of monocomponent grinding aid on compressive strength}

Effect of monocomponent grinding aid on compressive strength, As shown in figure 2: 


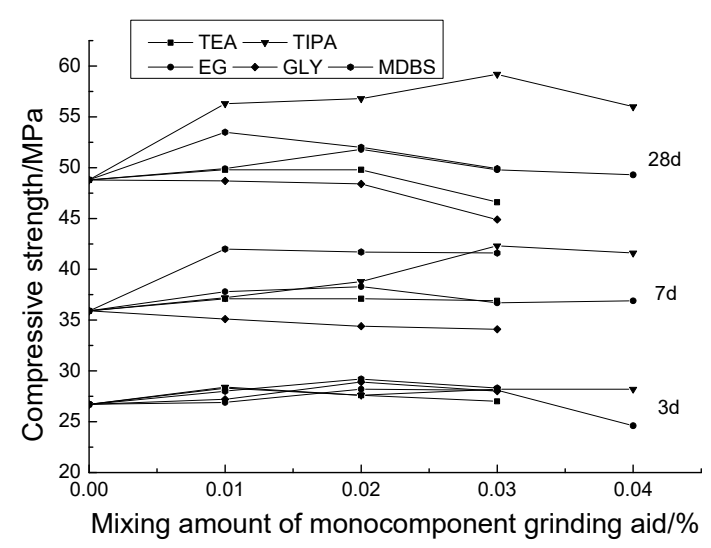

Fig.2 Effect of monocomponent grinding aid on compressive strength

As shown in figure 2, Every single-component grinding aid on growth of compressive strength of cement has a certain effect. Compared with the blank group, dosage of triethanolamine was $0.01 \%, 3 \mathrm{~d}, 7 \mathrm{~d}$ and $28 \mathrm{~d}$ compressive strength increased by $6.0 \%, 3.3 \%$ and $2.0 \%$; Three isopropyl alcohol amine content was $0.03 \%, 3 \mathrm{~d}, 7 \mathrm{~d}$ and $28 \mathrm{~d}$ compressive strength increased by $5.6 \%, 17.8 \%$ and $21.3 \%$; Ethylene glycol content was $0.02 \%, 3 \mathrm{~d}, 7 \mathrm{~d}$ and $28 \mathrm{~d}$ compressive strength increased by $5.6 \%, 6.7 \%$ and $6.1 \%$; Glycerin content was $0.02 \%, 3 \mathrm{~d}$ compressive strength increased by $8.2 \%$, but the $7 \mathrm{~d}$ and $28 \mathrm{~d}$ compressive strength with the increase of the content gradually reduced; Sorbitol content was $0.01 \%, 3 \mathrm{~d}, 7 \mathrm{~d}$ and $28 \mathrm{~d}$ compressive strength increased by $4.9 \%, 17.0 \%$ and $9.6 \%$.

To sum up, triethanolamine, three isopropanolamine, ethylene glycol and sorbitol have certain effect on cement fineness decreased, the improvement of specific surface area and the improvement of compressive strength of mortar, So according to the test results and economic cost, control components content in $0.01 \%, 0.01 \%, 0.02 \%$ and $0.01 \%$ respectively; Although glycerin has some effect of reduce the cement fineness, and the improvement of specific surface area, it has no improvement of compressive strength of mortar, even has a tendency to pour shrinkage, So the glycerin has a little contribution to the development of the cement strength.

\subsection{Grinding Aid Orthogonal Optimization Design}

\subsubsection{The Choice of factors Orthogonal Optimization Test}

In order to develop grinding agent, On the basis of the single component test, Choose triethanolamine (A), Three isopropyl alcohol amine (B), ethylene glycol (C) and sorbitol (D) 4 kinds of grinding aid as influence factors in the orthogonal experiment. The specific factors and levels as shown in table 4.

Tab.4 Orthogonal experimental factors and their levels

\begin{tabular}{ccccc}
\hline $\begin{array}{c}\text { factors } \\
\text { levels }\end{array}$ & $\mathrm{A} / \%$ & $\mathrm{~B} / \%$ & $\mathrm{C} / \%$ & $\mathrm{D} / \%$ \\
\hline 1 & 0.008 & 0.010 & 0.018 & 0.008 \\
2 & 0.010 & 0.012 & 0.020 & 0.010 \\
3 & 0.012 & 0.014 & 0.022 & 0.012 \\
\hline
\end{tabular}




\subsubsection{Orthogonal Test Results}

According to orthogonal design of experiment to test the 1-9 set of sample for adding grinding agent, the $10^{\text {th }}$ groups of blank sample without adding grinding agent, Orthogonal test table and different age compressive strength and compressive strength ratio as shown in table 5.

Tab.5 Orthogonal experimental table and results

\begin{tabular}{|c|c|c|c|c|c|c|c|c|c|c|}
\hline \multirow{2}{*}{$\begin{array}{l}\text { Test } \\
\text { no. }\end{array}$} & \multirow[t]{2}{*}{$\mathrm{A}(\mathrm{TEA})$} & \multirow[t]{2}{*}{ B (TIPA) } & \multirow[t]{2}{*}{$\mathrm{C}(\mathrm{EG})$} & \multirow[t]{2}{*}{$\mathrm{D}(\mathrm{MDBS})$} & \multicolumn{3}{|c|}{$\begin{array}{l}\text { compressive } \\
\text { strength } / \mathrm{MPa}\end{array}$} & \multicolumn{3}{|c|}{$\begin{array}{c}\text { compressive strength } \\
\text { ratio } / \%\end{array}$} \\
\hline & & & & & $3 d$ & $7 d$ & $28 d$ & $3 d$ & $7 d$ & $28 d$ \\
\hline 1 & $1(0.008)$ & $1(0.010)$ & $1(0.0$ & 10. & 30.9 & 42.3 & $z$ & 105.8 & 106.5 & 106.7 \\
\hline 2 & $1(0.008)$ & $2(0.012)$ & $2(0.020)$ & $2(0.010)$ & 29.8 & 42.5 & 58.8 & 102.1 & 107.1 & 109.7 \\
\hline 3 & $1(0.008)$ & $3(0.014)$ & $3(0.0$ & $3(0$. & 29.5 & 42.5 & 4 & 101.0 & 107.1 & 105.2 \\
\hline 4 & $2(0.010)$ & $1(0.010)$ & $2(0.020)$ & $3(0.0$ & 30.6 & 39.3 & 54 & 104.8 & 99.0 & 102.2 \\
\hline 5 & $2(0.010)$ & $2(0.012)$ & $3(0.022)$ & $1(0.008)$ & 28.1 & 39.5 & 51.6 & 96.2 & 99.5 & 96.3 \\
\hline 6 & $2(0.010)$ & $3(0.014)$ & $1(0.018)$ & $2(0.010)$ & 25.2 & 40.0 & 48.6 & 86.3 & 100.8 & 90.7 \\
\hline 7 & $3(0.012)$ & $1(0.010)$ & $3(0.022)$ & $2(0.010)$ & 30.0 & 39.8 & 52.5 & 102.7 & 100.3 & 97.9 \\
\hline 8 & $3(0.012)$ & $2(0.012)$ & $1(0.018)$ & $3(0.012)$ & 29.1 & 40.0 & 51.5 & 99.7 & 100.8 & 96.1 \\
\hline 9 & $3(0.012)$ & $3(0.014)$ & $2(0.020)$ & $1(0.008)$ & 30.6 & 39.8 & 48.5 & 104.8 & 100.3 & 90.5 \\
\hline 10 & / & / & / & / & 29.2 & 39.7 & 53.6 & 100 & 100 & 100 \\
\hline
\end{tabular}

\subsubsection{Experimental Result}

This experiment use the method of range analysis, The results of the analysis as shown in table 6 .

Tab.6 The range analysis results

\begin{tabular}{|c|c|c|c|c|c|c|c|c|c|c|c|c|}
\hline & \multicolumn{4}{|c|}{$\begin{array}{c}\text { Sum of } 3 \mathrm{~d} \text { compressive } \\
\text { strength of various factors } \\
\text { and range }\end{array}$} & \multicolumn{4}{|c|}{$\begin{array}{c}\text { Sum of } 7 \mathrm{~d} \text { compressive } \\
\text { strength of various factors } \\
\text { and range }\end{array}$} & \multicolumn{4}{|c|}{$\begin{array}{c}\text { Sum of } 28 \mathrm{~d} \text { compressive } \\
\text { strength of various factors } \\
\text { and range }\end{array}$} \\
\hline & A & B & $\mathrm{C}$ & $\mathrm{D}$ & A & B & $\mathrm{C}$ & $\mathrm{D}$ & A & B & $\mathrm{C}$ & $\mathrm{D}$ \\
\hline $\mathrm{I}_{\mathrm{j}}$ & 90.2 & 91.5 & 85.2 & 89.6 & 127.3 & 121.4 & 122.3 & 121.6 & 172.4 & 164.5 & 157.3 & 157.3 \\
\hline $\mathrm{II}_{\mathrm{j}}$ & 83.9 & 87 & 91 & 85 & 118.8 & 122 & 121.6 & 122.3 & 155 & 161.9 & 162.1 & 159.9 \\
\hline $\mathrm{III}_{\mathrm{j}}$ & 89.7 & 85.3 & 87.6 & 89.2 & 119.6 & 122.3 & 121.8 & 121.8 & 152.5 & 153.5 & 160.5 & 162.7 \\
\hline $\mathrm{K}_{\mathrm{j}}$ & 3 & 3 & 3 & 3 & 3 & 3 & 3 & 3 & 3 & 3 & 3 & 3 \\
\hline $\begin{array}{l}\mathrm{I}_{\mathrm{j}} / \\
\mathrm{K}_{\mathrm{j}}\end{array}$ & 30.07 & 30.50 & 28.40 & 29.87 & 42.43 & 40.47 & 40. & 40 & 57.47 & 54.83 & 52.43 & 52.40 \\
\hline $\begin{array}{l}\mathrm{II}_{\mathrm{j}} / \\
\mathrm{K}_{\mathrm{j}}\end{array}$ & 27.97 & 29.00 & 30.33 & 28.33 & 39.60 & 40.67 & 40.53 & 40.77 & 51.67 & 53.97 & 54.03 & 53.30 \\
\hline $\begin{array}{c}\mathrm{III}_{\mathrm{j}} / \\
\mathrm{K}_{\mathrm{j}}\end{array}$ & 29.90 & 28.43 & 29.20 & 29.73 & 39.87 & 40.77 & 40.60 & 40.60 & 50.83 & 51.17 & 53.50 & 54.23 \\
\hline $\mathrm{D}_{\mathrm{j}}$ & 2.10 & 2.07 & 1.93 & 1.54 & 2.83 & 0.3 & 0.24 & 0.24 & 6.64 & 3.66 & 1.60 & 1.83 \\
\hline
\end{tabular}


As shown in table 6, 4 kinds of single component grinding aid for $3 \mathrm{~d}$ the factors influencing the compressive strength of the size of $\mathrm{A}>\mathrm{B}>\mathrm{C}>\mathrm{D}$, The $7 \mathrm{~d}$ the factors influencing the compressive strength of the size of $A>B>C=D$, the $28 \mathrm{~d}$ the factors influencing the compressive strength of the size of $A>B>D>C$. In range analysis, the greater of range $D_{j}$, The greater the influence of the factors on the test. In orthogonal experiment, we can clearly see that the influence of grinding aids composition in the 4 factors. Based on analyzed of test results of $3 \mathrm{~d}, 7 \mathrm{~d}, 28 \mathrm{~d}$ compressive strength, Finally confirmed of A dosage of $0.008 \%$, B dosage of $0.01 \%$, C dosage of $0.02 \%$, D dosage of $0.01 \%$, it is the optimal ratio of grinding components.

\subsection{Effect of grinding aid of enhance component on cement performance}

on the basis on confirming of grinding components of grinding aids, study the composite cement grinding aid effect on the physical properties of cement by changing different inorganic reinforced components (as shown in table 7), The various components in proportion to configure form a homogeneous solution, Content is $0.1 \%$ (according to the quality of cement). Effect of different combinations on cement fineness, specific surface area and the influence of the compressive strength is shown in figure $3,4,5$.

Tab.7 Composite grinding aid of enhance component combination design $\quad / \%$

\begin{tabular}{|c|c|c|c|c|c|c|}
\hline NO. & $\begin{array}{c}\text { Grinding } \\
\text { combination }\end{array}$ & $\mathrm{Na}_{2} \mathrm{SO}_{4}$ & $\mathrm{Na}_{2} \mathrm{~S}_{2} \mathrm{O}_{3}$ & $\mathrm{Na}_{2} \mathrm{CO}_{3}$ & $\mathrm{NaOH}$ & other \\
\hline 0 & 1 & I & I & 1 & 1 & 1 \\
\hline 1 & 48 & & & & & 52 \\
\hline 2 & 48 & 10 & & & 10 & 32 \\
\hline 3 & 48 & 20 & & & 10 & 22 \\
\hline 4 & 48 & & 5 & & 10 & 37 \\
\hline 5 & 48 & & 10 & & 10 & 32 \\
\hline 6 & 48 & & & 5 & 10 & 37 \\
\hline 7 & 48 & & & 10 & 10 & 32 \\
\hline
\end{tabular}
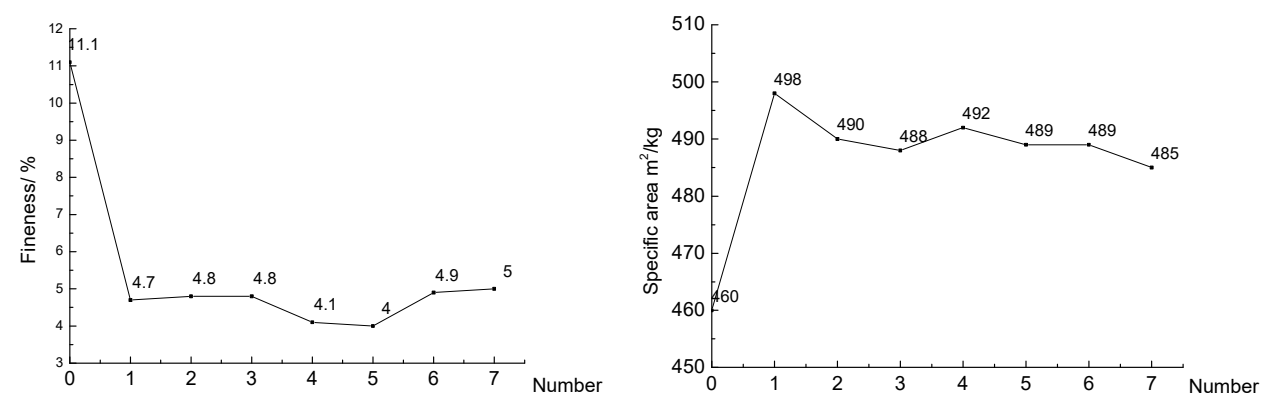

Fig.3 Effect of different combinations of cement fineness Fig.4 Effect of different combinations

of specific area 


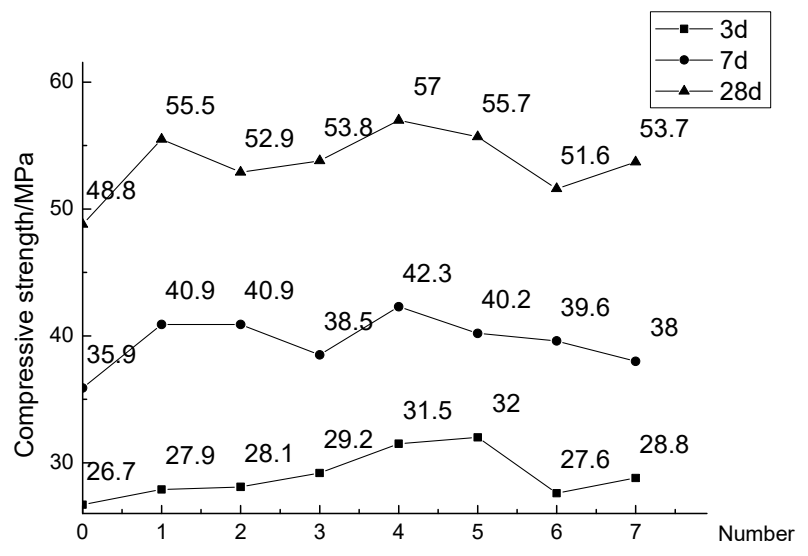

Fig.5 Effect of different combinations of cement compressive strength

From Figure 3, 4 and 5, Compared with no addition of inorganic enhancement component No.1 (Sample No. 0 not included, Cement fineness and specific surface area have no significantly change. The compressive strength of cement mortar at various ages is increased, Among them, the compressive strength of the No.4 cement samples increased a lot at different ages. The analysis shows, There was no obvious change in cement fineness and specific surface area after the addition of inorganic components, The results show that the inorganic strengthening component has no significant effect on the reduction of cement fineness and the increase of specific surface area. The best combination of compound grinding aids is grinding aids. $\mathrm{Na}_{2} \mathrm{~S}_{2} \mathrm{SO}_{3}$ and $\mathrm{NaOH}$. From the test results, The $\mathrm{Na}_{2} \mathrm{~S}_{2} \mathrm{SO}_{3}$ optimum dosage was $0.005 \%$ (According to cement quality), $\mathrm{NaOH}$ optimum dosage was $0.001 \%$ (According to cement quality),Compared with the No.0 cement samples , No. 4 cement samples make cement fineness decreased 63.1\%, The compressive strength of $3 \mathrm{~d}, 7 \mathrm{~d}$ and $28 \mathrm{~d}$ increased by $17.9 \%, 17.8 \%$ and $16.8 \%$, respectively, Specific surface area increased by $10.6 \%$.

\subsection{Effect of Grindling Aids on Cement Particle Size Distribution}

Through the research on the preparation of cement composite cement fineness and specific surface area and compressive strength had a good effect of grinding aids. The cement particle size distribution of No. 4 cement sample with adding cement grinding aid and No. 0 cement sample without adding cement grinding aid was tested. The results are shown in Table 8 and Figure 6.

Tab. 8 Test result of two kind cement particle size distribution

\begin{tabular}{cccccccc}
\hline \multirow{2}{*}{ Sample number } & \multicolumn{7}{c}{ Particles size distribution of cement/\% } \\
\cline { 2 - 8 } & $<1 \mu \mathrm{m}$ & $1-3 \mu \mathrm{m}$ & $3-10 \mu \mathrm{m}$ & $10-32 \mu \mathrm{m}$ & $32-60 \mu \mathrm{m}$ & $>60 \mu \mathrm{m}$ & $3-32 \mu \mathrm{m}$ \\
\hline $\mathbf{0}$ & 3.45 & 10.43 & 22.59 & 34.94 & 21.44 & 7.15 & 57.53 \\
$\mathbf{4}$ & 4.93 & 13.92 & 26.62 & 37.41 & 16.23 & 0.89 & 64.03 \\
\hline
\end{tabular}




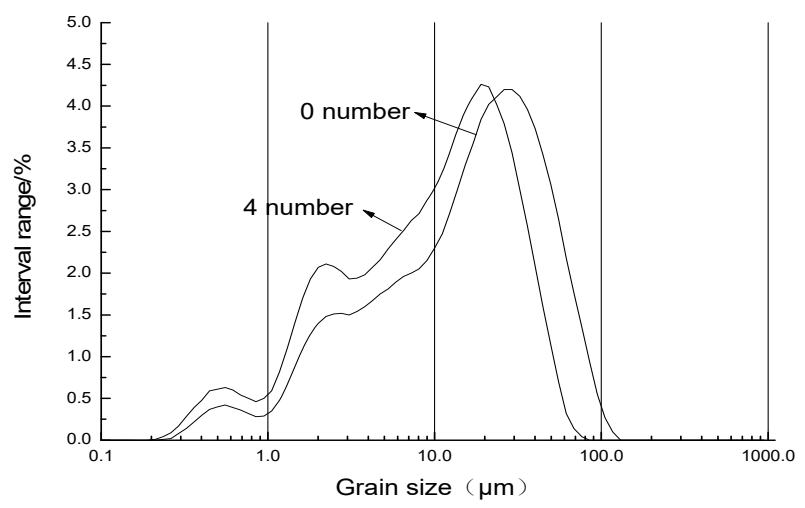

Fig.6 Size distribution curve of cement

Hydration rate of cement mainly depends on the size of cement particle.. 0-10 um particle is close to full hydration at $28 \mathrm{~d} ; 10-32$ microns particles is half hydration at $7 \mathrm{~d} ; 32-60$ um particle is half hydration at $28 \mathrm{~d}$, The particles larger than $60 \mathrm{~m}$ were less than half hydration even after 3 months. As can be seen from table 8 and figure 6 , The size range of cement $0-10$ um increased by $24.68 \%$ with the composite grinding aid, The size range of $1-3$ um increased by $33.46 \%$, The early compressive strength increased significantly. The content of cement particles is lower than $60 \mathrm{um}$, Improve the utilization ratio of cement; 3-32 um size range increased by $11.30 \%$, Cement hydration reaction, The $28 \mathrm{~d}$ compressive strength of cement mortar is improved, The particle size distribution of cement particles was optimized.

\section{Grinding and Enhancement Mechanism}

Cement grinding aid used in cement grinding process, Grinding agent in the molecular adsorption on cement particle surface ${ }^{[9-10]}$, between the micro cracks, Can reduce the cement particle surface free energy, and crackle $\mathrm{Ca}-\mathrm{O}$ ionic bond and covalent bond rupture after Si-O produce unsaturated charge, Stop $\mathrm{Ca}^{2+}$ and $\mathrm{O}^{2-}$ back together (theoretical model shown in figure 7), improve the dispersion of fine particles, improve the material liquid inside the mill, improve grinding efficiency. However, the molecular structure of the different grinding agent is different, it leads to the different grinding aid grinding dispersion effect., And cement in different mineral compositions during grinding with different grinding mechanism, Such as $\mathrm{C}_{2} \mathrm{~S}$ mineral need depolymerization, And mineral $\mathrm{C}_{3} \mathrm{~S}$ need crack stress corrosion crack propagation. So in the process of cement grinding, using only a molecular structure of grinding aid can appear the function is not perfect, the effect of one sector ${ }^{[11]}$. So you need to different molecular structure of grinding aid distribution in use, you will get very significant results.

Add inorganic salt and $\mathrm{NaOH}$ in grinding agent system can promote the precipitation of $\mathrm{Ca}^{2+}$ in the cement mortar system, In the system of colloidal $\mathrm{Ca}^{2+}$ fast saturated state, Silicate ions can produce $\mathrm{C}-\mathrm{S}-\mathrm{H}$ combined with $\mathrm{Ca}^{2+}$, promote the cement hydration reaction, improve the strength of cement at early stage. 
(a)

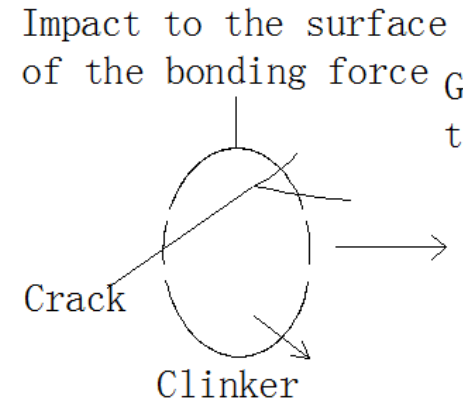

Impact to the surface

of the bonding force

(b)

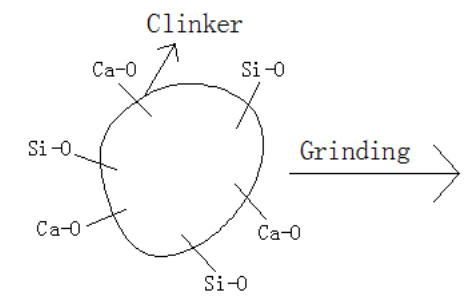

Grinding aids adsorption on the surface crack

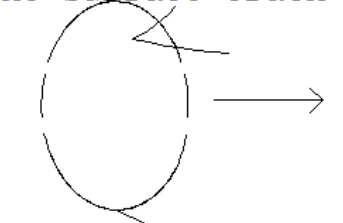

Weakened bonding force by adsorption

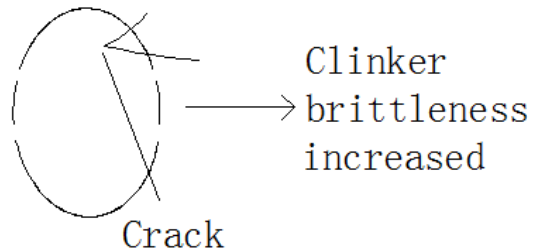

propagation

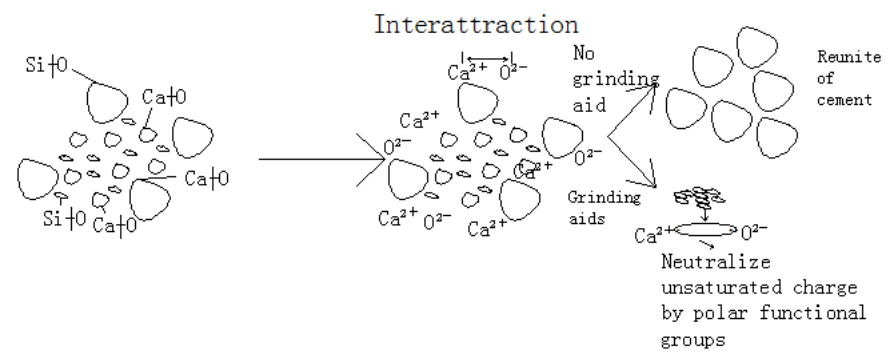

Fig.7 Grinding mechanism (a) adsorption model (b) split valence bond theory model

\section{Conclusions}

(1) The ratio of grinding aids was determined by experiment: TEA was $0.008 \%$, TIPA was $0.01 \%$, EG was $0.02 \%$, MDBS was $0.02 \%, \mathrm{Na}_{2} \mathrm{~S}_{2} \mathrm{O}_{3}$ was $0.005 \%, \mathrm{NaOH}$ was $0.01 \%$.

(2) Compared with black sample, Development of grinding aids can reduce $63.1 \%$ cement fineness, specific surface area increased by $10.6 \%$; cement particles ranging $3-32 \mu \mathrm{m}$ is improved $11.3 \%$, which optimizes the grain composition of cement.

(3) Compared with blank sample, The developed grinding aids have the effect of promoting hydration, $3 \mathrm{~d}, 7 \mathrm{~d}$ and $28 \mathrm{~d}$ respectively are improved $17.9 \%, 17.8 \%$ and $16.8 \%$, increases strength of compression cement.

\section{References}

[1] Jiang C X. Study on high performance grinding aids of cement [J].Journal of the Chinese Ceramic Society, 2001,29 (6) : 508-511.

[2] Gao X J, Yang Y Z, Deng H W. Utilization of beet molasses as a grinding aid in blended cements [J] . Construction and Building Materials, 2011, 25(9):3782-3789.

[3] Shao H J, Zhang D C. Study on high performance recombination grinding aids of cement [J]. Building Materials of Shandong, 2000, (6) : 1-3.

[4] Wang Y P. Zhang T S, Tong G Q. Study on recombination grinding aids of cement[J].Cement, 2002，（8）: $8-10$.

[5] Teoreanu I, Guslicoy G. Mechanisms and effects of additives from the dihydroxy- compound class on Portland cement grinding [J] . Cement and Concrete Research, 1999, 29(1):9- 15.

[6] Choi H, Lee W. Kim D U, et al. Effect of grinding aids on the grinding energy consumed during grinding of calcite in a stirred ball mill $[\mathrm{J}]$. Minerals Engineering, 2010, 23(1)54- 57.

[7] Zhao J H, Wang D M. Wang X G. Formulation Design of Grinding Aids and It is Effect on the properties of 
Cement[J]. Bulletin of the Chinese Ceramic Society, 2014,33 (4) : 724-730.

[8] Chen S L. Application Guide of Cement Grinding Aids [M]. Bei Jing, Chinese building materials industry publication.2014:200.

[9] Zhang X P, Huang C Y. The progress of cement grinding aid in China and the development tendency[J].Cement, 2014, (9): 17-20.

[10] Qian H, Fang Y, Li Z. The research and development situation of cement grinding aid[J]. New Chemical Materials, 2014,42 (1) : 27-29.

[11] Jiang $\mathrm{C} \mathrm{H}$. New type of grinding aid and the process research of under the action of cement ultra-micronization model[D].Nan Jing: Phd thesis of nan jing university of technology,2001. 